\title{
CLINICS IN SPORTS MEDICINE
}

\section{FORTHCOMING ISSUES}

\section{October 2020}

Foot and Ankle Injuries and Treatment Joseph S. Park and Anish R. Kadakia, Editors

January 2021

Sport-Related Concussion

Peter Kriz, Editor

April 2021

Athletic Injuries of the Hip Dustin Richter and F. Winston

Gwathmey Jr, Editors

\section{RECENT ISSUES}

April 2020

Nuances in the Management of Hand and Wrist Injuries in Athletes

Sanjeev Kakar, Editor

January 2020

Meniscus Injuries

Brett D. Owens and Ramin R. Tabaddor, Editors

October 2019

Top 10 Primary Care Training Room

Conditions

Siobhan M. Statuta and John M.

Macknight, Editors

\section{SERIES OF RELATED INTERESTED}

Orthopedic Clinics

Foot and Ankle Clinics

Hand Clinics

Physical Medicine and Rehabilitation Clinics

Clinics in Podiatric Medicine and Surgery

THE CLINICS ARE AVAILABLE ONLINE!

Access your subscription at: 